Kamila Doktor-Bindas, Ph.D., lecturer

Department of Constitutional Law

The John Paul II Catholic University of Lublin

\title{
PROTECTION OF PRINCIPLE OF THE RULE OF LAW IN RELATIONS BETWEEN THE EUROPEAN UNION AND THE REPUBLIC OF POLAND
}

\begin{abstract}
Summary
It is indisputable that the European Union is currently facing the greatest crisis since its creation. One of its causes is the issue related to the failure to follow the rule of law in some Member States, including Poland. This has resulted in a certain "awakening" in the protection mechanisms of the rule of law by the EU institutions, which is proven by their firm reaction to the Polish reforms regarding the judiciary. The fate of the EU as "the Union of principles" currently hangs in the balance, and each member state has to clearly determine its position in the organisation regarding this situation.
\end{abstract}

Keywords: rule of law, Court of Justice of the EU, justice administration system

\section{Introduction}

The rule of law, being one of the fundamental principles that uphold the functioning of the European Union, is a complex subject, impossible to describe within the limits of a single academic article. The issues raised in this study will be limited to being indicatory in nature, and they will only point out the main problems related to the rule of law in the sphere of relations between Poland and the European Union.

\section{The concept and significance of the rule of law}

The rule of law constitutes an element in the heritage of the EU Member States, and its universal function consists of the limitation of power by law, the protection of individuals against arbitrary power, and ensuring priority and dignity to the individual ${ }^{1}$. The essence of the rule is contained in Article 2 of the Treaty on European Union (TEU) and simultaneously constitutes one of the basic

Taborowski M. Mechanizmy ochrony praworządności państw członkowskich Unii Europejskiej. Studium przebudzenia systemu ponadnarodowego [Mechanisms to protect the rule of law of the European Union Member States. Study of the awakening of the supranational system]. Warsaw: Wolters Kluwer, 2019, p. 59; 
constitutional principles of the $\mathrm{EU}^{2}$ and the Member States, which, by joining the organisation, are obliged to respect and support this principle. In accordance with the so-called First Copenhagen Criterion, as specified in the Copenhagen Declaration of June $1993^{3}$, the accession of new states requires that

[..] the candidate country has achieved stability of institutions guaranteeing democracy, the rule of law, human rights and respect for and protection of minorities $[. .]^{4}$.

However, Article 2 of the TEU does not further specify the concept of the rule of law, consequently, for this rule to be applicable, it should be replete with content, which is the responsibility of the Court of Justice of the EU (CJEU).

The legal science considers the rule of law as an umbella principle, which in its essence is a meta-principle, encompassing the tenets with specific normative significance in the EU legal system ${ }^{5}$. From the practical perspective, there are many sources providing elements forming the rule of law. One of the most important is definitely the Communication from the Commission on the Rule of Law of 2014 ("A new EU Framework to strengthen the Rule of Law"). It contains a set of six main principles of EU law, constituting, in the opinion of the Commission, the foundation of the rule of law within the meaning of Article 2 of the TEU: legality, legal certainty, the prohibition of arbitrariness in executive powers, independent and impartial courts, the separation of powers, and equality before the law. Essentially, all these principles either constitute the general principles of EU law or they have their source in the case law of the CJEU, or they are protected according to the Charter of Fundamental Rights.

\section{Polish regulations concerning the rule of law}

When Poland was at the stage of aspiring to the European Union membership, it had to accept the core values underlying the existence and functioning of the

2 As follows: Communication from the Commission to the European Parliament and the Council. a new EU Framework to strengthen the Rule of Law, Strasbourg, 11/03/2014, COM(2014) 158 final, p. 2; see more on the subject of the Communication: Prostak R. Nienaruszalnosć unijnego systemu wartości jako żywotny interes Unii Europejskiej-krytyczna analiza mechanizmu egzekucji postanowień art. 2 Traktatu o Unii Europejskiej [Inviolability of the EU value system as a vital interest of the European Union - a critical analysis of the enforcement mechanism of Article 2 of the Treaty on European Union]. Zeszyty Naukowe Uniwersystetu Ekonomicznego w Krakowie [Cracow Review of Economics and Management]. No. 7, 2017, p. 92; Würtenberger T., Tkaczyński J. W, Nowe ramy Unii Europejskiej na rzecz umocnienia praworządności [A new European Union framework for strengthening the rule of law]. Panstwo i Prawo [The State and the Law], No. 9, 2017.

3 European Council, Conclusions of the Presidency, Copenhagen, 21-22/06/1993, DOC/93/3.

4 Barcz J. Unia Europejska wobec niepraworządnego państwa członkowskiego [The European Union in relation to a Member State failing to abide the law]. Państwo i Prawo [The State and the Law], No. 1, 2019, pp. 4-5.

5 Taborowski M. 2019, p. 61; the author quotes Pech L. The Rule of Law as a Constitutional Principle. Jean Monnet Working Paper Series, No. 4, 2009, p. 49 and 53, and Marshall G. The Rule of Law. Its Meaning, Scope and Problems. Cahiers de philosophie politique et juridique, No. 24, 1993, p. 43. 
entire organisation. However, the rule of law clearly arises from the provisions of our constitution of 17 October 1997: "The organs of public authority shall function on the basis of, and within the limits of the law". According to the understanding adopted in Polish constitutional law, this tenet is equated to the principle of the legality of the public-authority bodies, which basically means that they operate on the basis and within the limits of the law. The law, in turn, determines their tasks and competences, as well as the procedure for issuing decisions in the form and legal basis prescribed by the law and in compliance with the substantive regulations binding on a particular body ${ }^{6}$. Furthermore, it should be emphasised that the rule of law is a component of the state of the law and from a chronological perspective this is its source and it should be interpreted through such dimension ${ }^{7}$.

\section{Poland and the European Union - a story of a difficult relationship}

Regardless of the unanimous assurances by the Polish Constitutional Tribunal included in the judgement of 11 May 2005 on the Treaty on the accession by the Republic of Poland to the EU ${ }^{8}$ concerning Poland's membership of the union of law and the community of values such as democracy, and the rule of law, the issue of the rule of law at a certain time became a moot point between Poland and the EU. Since 13 January 2016, the European Commission has been conducting a structural dialogue with Poland on the matter of the rule of law in our country, issuing successive

6 Sokolewicz W. Komentarz do art. 7 Konstytucji RP z 2 kwietnia 1997 r. [Commentary to Article 7 of the Constitution of the Republic of Poland of 2 April 1997]. In: Konstytucja Rzeczypospolitej Polskiej. Komentarz [Constitution of the Republic of Poland. Commentary], Vol. 5, Garlicki L. (ed.), Warsaw: Wydawnictwo Sejmowe 2007, p. 5; Skrzydło W., Konstytucja Rzeczypospolitej Polskiej z dnia 2 kwietnia 1997 r. Komentarz [Constitution of the Republic of Poland of 2 April 1997. Commentary]. Cracow, 1998, p 15; Winczorek P. Komentarz do Konstytucji Rzeczypospolitej Polskiej z dnia 2 IV 1997 r. [Commentary to Article 7 of the Constitution of the Republic of Poland of 2 April 1997]. Warsaw, 2000, p. 19; Morawska E. Klauzula państwa prawnego w Konstytucji RP na tle orzecznictwa Trybunału Konstytucyjnego [The rule of law clause in the Constitution of the Republic of Poland against the background of the Constitutional Tribunal's jurisprudence]. Toruń, 2003, pp. 41-42; see also Tuleja P. Komentarz do art. 7 Konstytucji RP [Commentary to Article 7 of the Constitution of the Republic of Poland]. In: Konstytucja RP, Komentarz [Constitution of the Republic of Poland. Commentary]. Vol. 1, Safjan M., Bosek L. (eds.), Warsaw: CH Beck, 2016, p. 303; Judgement of the Polish Constitutional Tribunal Ts 216/04 of 9 May 2005, OTK ZU 2006, series B, No. 2, item 87.

7 Sokolewicz W. 2007, p. 3; more on the subject of the concept of democratic principles of the state of law cf. i.a. Czarnek P. Zasada państwa prawa [Rule of law]. In: Zasady Ustroju III Rzeczypospolitej Polskiej [The Principles of the Third Republic of Poland]. Dudek D. (ed.), Warsaw: Wolters Kluwer, 2009, pp. 156-189; Tuleja P. Zastane pojęcie państwa prawnego [The concept of the rule of law as established]. In: Wronkowska S. (ed.), Zasada demokratycznego państwa prawnego w Konstytucji RP [The principle of a democratic state of law in the Constitution of the Republic of Poland], Warsaw, 2006.

8 Judgement of the Polish Constitutional Tribunal K 18/04 of 11 May 2005, OTK-A 2005/5, item 49. 
recommendations on this matter addressed to the Polish authorities ${ }^{9}$. Regarded as the culmination of these activities was, arguably, the proposal by the European Commission of 20 December 2017, adopted pursuant to Article 7(1) of the TEU, on identifying of a clear risk of a serious breach of the rule of law by Poland (the first proposal of such kind in the history of the EU). Simultaneously with the proposal (apart from the fourth recommendation), the Commission decided to take another step in the infringement proceedings against Poland (for a breach of the EU law and the adoption of the Act on the Common Court System), and to bring the matter before the Court of Justice of the European Union. These events initiated an ongoing political and academic debate in Poland and abroad, and relations between Brussels and Warsaw had never been this tense. The situation still retains its dynamics, and new issues related to the matters discussed in this article appear almost on a daily basis. At the beginning of October 2019, the CJEU received a new complaint from the European Commission (the third one in the sequence), according to which, the system of discipline for judges introduced by the provisions of Polish acts undermined the independence of the representatives of the Polish justice system, and did not ensure the necessary guarantees facilitating protection against control by the politicians. The Commission passed a motion for implementing scrutiny according to the expedited procedure, leading to the assumption that the decision of the CJEU on this matter would be issued within a few months. Very soon, on 5 November 2019, we will get to know the decision of the CJEU on the complaint by the European Commission regarding the provisions of the Act on the Common Court System (the complaint was lodged in March 2018). According to the CJEU Advocate General, Prof. Evgeni Tanchev, the provisions contested by the Commission are incompatible with EU law ${ }^{10}$.

\section{The position of the Court of Justice of the EU with regard to the Polish Supreme Court}

The case regarding the complaint by the European Commission on the matter of the violation by the Polish legislator of the fundamental tenets of the law of the EU, including the principle of judicial independence, lodged before the CJEU was recently decided. The CJEU announced its judgement in this case on 24 June 2019 (the judgement of the CJEU, Grand Chamber, in case C 619/18), with a prior decision to apply interim measures with regard to Poland in the form of an order to suspend the application of the provisions of the Law on the Supreme Court

9 See also the White Paper on the reforms of the Polish justice system presented by the Prime Minister of the Republic of Poland Mateusz Morawiecki at the meeting with the President of the European Commission Jean-Claude Juncker on 08/03/2018, which is treated as participation in the discussion on behalf of the Polish authorities (available at www.premier.gov.pl).

10 Opinion of Advocate General Evgeni Tanchev of 20 June 2019, ECLI:EU:C:2019:529; see also the earlier opinion of the same Advocate of 11 April 2019 on case C-619/18; both available on the website: www.curia.europa.eu. 
on the retirement age for judges of the Supreme Court (thereby concurring with the request of the European Commission).

At this point, the significance of the interim measures mentioned above should be emphasised, as they provoked a clear reaction by the Polish authorities. The consequence was the restoration of the original legal status (restitutio in integrum) from before the adoption of the controversial provisions. At the same time, the Polish state, by the mere fact of the application of the decision, committed to refrain from any other activities aimed at impeding or negating the purposes of the interim measure.

The radicalism, the far-reaching consequences of this measure, and its distinctiveness (as it differs from the interim measures known to Polish law) gave rise to much political and academic discussion in our country ${ }^{11}$. The main problem, which appeared in relation to the discussed matter, was the question of whether the order issued by the CJEU created an independent legal basis for reinstatement of the judges of the Supreme Court to their previous posts. Finally, in order to apply the interim measures, the Polish authorities adopted an act amending the disputed provisions of the national law ${ }^{12}$. However, this fact did not stop the CJEU from adopting the judgement in this case.

The judgement of the CJEU concerned amendments to the Law on the Supreme Court adopted in 2018, which instituted, among other things, the lowering of the retirement age for judges of the Supreme Court and the Supreme Administrative Court from the age of 70 to 65 years. The CJEU emphasised that the disputed provisions of the Law on the Supreme Court breached the principle of the irremovability of judges, and judicial independence, thereby contravening the EU law. The Court also added that the guarantees regarding the independence and impartiality of judges require the authority in question to perform its duties in fully autonomous manner, protected from external pressure or interference.

\section{The consequences of failure to observe the rule of law}

Consequently, as it appears, at present the issue of the rule of law is the main factor governing relations between Poland and the EU. The essential question in this regard is what are the consequences for both parties.

Clearly, the crisis of the rule of law in any Member State has a negative impact on the entire EU, and exceptional measures would be required in the case

11 More on this subject: Kmieciak Z. Ochrona tymczasowa w sprawie skargi Komisji przeciwko Polsce dotyczącej przepisów ustawy obniżającej wiek przejścia w stan spoczynku sędziów SN. Glosa do postanowienia TSUE z 19.10. 2018 [Interim protection in the case of the Commission's complaint against Poland concerning the provisions of the act lowering the retirement age for the judges of the Supreme Court. Gloss to the CJEU decision of 19 October 2018]. C-619/18 R, Państwo i Prawo [The State and the Law], No. 1, 2019, p. 145.

12 The Law of 21 November 2018 amending the Law on the Supreme Court (Journal of Laws, item 2507), which entered into force on 01 January 2019. 
of a systemic crisis $^{13}$. From this perspective, it should be noted that to a certain extent the EU has "activated" its system of supranational protection, ${ }^{14}$ and the actions of the Polish authorities are largely responsible for that. As a result of its actions, the Republic of Poland is the only country having been covered by all the proceedings before the CJEU aimed at the protection of the rule of law ${ }^{15}$. These include the protection resulting from the procedure of Article 7 of the TEU, and the protection resulting from initiation of the preliminary ruling procedure pursuant to Article 267 of the TFEU (i.e., in practice, protection implemented by national courts).

Notably, the introduction of the procedure in accordance with Article 7 of the TEU was directly related to expanding of European integration with the states of Eastern-Central Europe, including the former states of the Soviet bloc ${ }^{16}$. Due to the fact that for a certain time among the Member States of the EU there have been systemic cases where the rule of law has been breached, the procedure under Article 7 of the TEU is increasingly frequently being perceived as a procedure with the repressive function (the initiation of sanction mechanism under Article 7(3) of the TEU) and isolating (aimed at protecting other EU states from the effects of the breach of values under Article 2 of the TEU) ${ }^{17}$.

The procedure regulated by Article 258 of the Treaty on the Functioning of the European Union (TFEU) enables the Commission (as the "guardian of the Treaties") and the Member States (by Article 259 of the TFEU) to supervise the application of EU law by the countries, which belong to the $\mathrm{EU}^{18}$. The establishment of an infringement by the CJEU in the manner specified above results in an obligation imposed on a Member State to eliminate the infringement (Article 260 of the TFEU), and, if it fails to do so (i.e., fails to apply the order identifying the infringement), a penalty payment may be imposed (Article 260(2) of the TFEU), but this is not subject to the consent of the Member State. Although the indicated procedure was not constructed directly as a mechanism for the protection of the rule of law, the Commission has started to use it effectively in

13 Safjan M. Rządy prawa a przyszłość Europy [The rule of law and the future and the future of Europe]. Europejski Przeglad Sądowy [European Judiciary Review], No. 8, 2019, p. 1.

14 Using the definition of Taborowski M. presented in monograph cited above.

15 On the subject of the effectiveness of the mechanisms of the rule of law, see: Grzeszczak M. Skuteczność unijnych procedur ochrony praworządności w stosunku do państw członkowskich [Effectiveness of EU procedures for protecting the rule of law in relation to Member States]. Państwo $i$ Prawo [The State and the Law], No. 6, 2019, pp. 28-54.

16 Kochenov D. Busting the Myths Nuclear: a commentary on Article 7 TEU, EUI Working Paper, Law 2017/10, pp. 4-5.

17 Mik C. Komentarz do art. 7 TUE [Commentary on Article 7 TEU], In: Traktat o Unii Europejskiej. Komentarz [Treaty on European Union. Comment]. Mik C., Czapliński W. (eds.), Warsaw 2005, p. 95; on the subject of the of the essence and origins of procedure; see also Galster J., Lis-Staranowicz D. Doktryna Point of no return w prawie Unii Europejskiej. Ratione materiae wobec ratione temporis [The point of no return doctrine. Ratione materiae towards ratione temporis], Państwo i Prawo [The State and the Law], No. 7, 2017, p. 18 et seq. Barcz J. 2019, p. 11.

18 Taborowski M. 2019, p. 215. 
practice, which is proven by the aforementioned complaints regarding the Supreme Court, common courts and the disciplinary measures for the judges.

The last mechanism related to the preliminary ruling procedure (Article 267 TFEU) engages courts of EU Member States in protecting the essential rules of the supranational system, and it is a significant link in cooperation between them and the CJEU. It should be kept in mind that many essential principles on which the functioning of the EU is based have been developed precisely within the framework of this procedure, and the one, which is germane to the matters discussed here, is the rule of law ${ }^{19}$. At the moment, there are pending 14 requests for preliminary rulings submitted by Polish courts, which mainly ask whether certain elements of the judicial reforms of the ruling majority are lawful, such as the appointment of the new National Council of the Judiciary of Poland, the status of the newly-created Disciplinary Chamber of the Supreme Court, and a new model for disciplining judges ${ }^{20}$.

One should definitely add to the aforementioned procedures inclusion of Poland in the proceedings pursuant to the Communication of 11 March 2014, aiming to ensure "effective and coherent protection of the rule of law in all Member States" ${ }^{21}$. These proceedings are separate from those noted above, and in fact their function is preparatory for the procedure under Article 7 of the TEU (although their assumption is, in general, to avoid it) 22 .

Launching the aforementioned procedures obviously has a multidimensional impact on Poland, and this is not solely limited to the issue raised most often in public debate, i.e., financial sanctions from the EU. Legal science emphasises the existence of other severe consequences of a Member State's failure to follow the rule of law, such as the isolation of the state, the limitation of funds from the EU budget, the exclusion of the influence of the state on the further systemic

19 Cf. i.a. the judgement of the CJEU of 11 November 2005, C-144/04, Werner Mangold v. Rüdger Helm, ECLI:EU:C:2005:709; the judgement of 27 February 2018, C-64/16, Associação Sindical dos Juízes Portugueses v. Tribunal de Contas, ECLI:EU:C:2018:117 and the commentary on the judgement, Bogdanowicz P., Jak Trybunał Sprawiedliwości “aktywował” art. 19 ust. 1 TUE w kontekście praworządności: uwagi na tle sprawy C-64/16 [How the Court of Justice "activated” Article 19(1) TEU in the context of the rule of law: comments against the background of case C-64/16]. Associação Sindical dos Juízes Portugueses. In: Sądowe mechanizmy ochrony praworządności w Polsce w świetle najnowszego orzecznictwa Trybunału Sprawiedliwości Unii Europejskiej [Judicial mechanisms for the protection of the rule of law in Poland in the light of recent judicial decisions of the Court of Justice of the European Union], Barcz J., Łojek-Zawidzka A. (eds.), Warsaw, 2018.

20 On 19 November, the judgement of the CJEU will be announced on the requests of the Supreme Court and the Supreme Administrative Court on the Disciplinary Chamber of the SC. Advocate General Evgeni Tanchev issued a very negative opinion regarding this chamber and the new National Council of the Judiciary, participating in the appointment of its judges; the opinion of the Advocate General on joined cases C-585/18, C-624/18 and C-625/18, the National Council of the Judiciary and others is available at www.curia.europa.eu.

21 Communication, p. 3; The proceedings conducted by the Commission based on the Communication are referred to as "a mechanism" in the Communication itself, as well as by the CJEU, e.g. in the Order of 17 December 2018, C-619/18 R, Commission v. Poland, Clause 81.

22 Taborowski M. 2019, p. 150. 
development of the EU, exit (or even exclusion) from the Union ${ }^{23}$. One should also add the internal results of the conflicts arising between Poland and the EU, such as the noticeable political and social crisis, exacerbating the already considerable division among the citizens of our country. It seems that the winning of the recent parliamentary elections by the Prawo i Sprawiedliwość party, which is openly sceptical towards the previous concept of European integration, will not improve the situation.

\section{Conclusions}

The scale of current challenges to the process of European integration by the EU Member States is immense and, depending on how these challenges will be the addressed, the further direction of the development of this process and the position of particular States within it will be determined ${ }^{24}$. If the organisation is to remain "the Union of principles"25 ("the Union of values"26), it seems that consistency and determined actions to reinforce the protection system of supreme values are the only possible direction. The author thinks that the question regarding states' position in the organisation has to be answered individually by each country through the dimension of its own expectations towards European integration. It could be resolved either following the path of compromise and dialogue, or in the manner chosen by the UK. However, are we really going to respond to all the doubts currently being raised in political debate in Poland by going as far as leaving the organisation, despite having aspired to the membership for many years within the framework of democratic transformations, leaving behind us the experience of totalitarianism and exclusion?

\section{BIBLIOGRAPHY}

\section{Literature}

1. Barcz J. Unia Europejska wobec niepraworządnego państwa [The European Union in relation to a Member State failing to abide the law]. Panstwo i Prawo [The State and the Law], No. 1, 2019.

2. Barcz J. Różnicujący się proces integracji europejskiej a Polska [The diversifying European integration process and Poland]. In: Polska w Unii Europejskiej. Nowe wyzwania [Poland in

23 Barcz J. 2019, pp. 11-20.

24 Barcz J. Różnicujący się proces integracji europejskiej a Polska [The diversifying European integration process and Poland]. In: Polska w Unii Europejskiej. Nowe wyzwania [Poland in the European Union. New challenges]. Barcz J., Domaradzki S., Kuligowski R., Szewczyk M., Szklarczyk-Amati E. (eds.) The European Commission Representation Office in Poland: Warsaw, 2018, p. 30.

25 Safjan M. 2019, No. 8, p. 6 et seq.; perceives the EU mainly as an economic union. Rulka M. Unijna kontrola praworządności-uwagi de lege ferenda [EU control of the rule of law - de lege ferenda remarks]. Studia Europejskie [Studies in European Affairs], No. 2, 2016, pp. 54-55.

26 Von Bogdandy A. Tyrania wartości? Problemy i drogi europejskiej ochrony praworządności krajowej [Tyranny of values? Issues and methods in the protection of the rule of law in Europe]. Europejski Przegląd Sądowy [European Judiciary Review], No. 4, 2019, pp. 4-11. 
the European Union. New challenges]. Barcz J., Domaradzki S., Kuligowski R., Szewczyk M., Szklarczyk-Amati E. (eds.), The European Commission Representation Office in Poland: Warsaw, 2018.

3. Bogdanowicz P. Jak Trybunał Sprawiedliwości "aktywował" art. 19 ust. 1 TUE w kontekście praworządności: uwagi na tle sprawy C-64/16 [How the Court of Justice "activated" Article 19(1) TEU in the context of the rule of law: comments against the background of case C-64/16]. Associação Sindical dos Juízes Portugueses. In: Sądowe mechanizmy ochrony praworządności w Polsce w świetle najnowszego orzecznictwa Trybunału Sprawiedliwości Unii Europejskiej [Judicial mechanisms for the protection of the rule of law in Poland in the light of recent judicial decisions of the Court of Justice of the European Union], Barcz J., Łojek-Zawidzka A. (eds.), Warsaw, 2018.

4. Czarnek P. Zasada państwa prawa [Rule of law] In: Zasady Ustroju III Rzeczypospolitej Polskiej [The Principles of the Third Republic of Poland]. Dudek D. (ed.), Warsaw: Wolters Kluwer, 2009.

5. Galster J., Lis-Staranowicz D. Doktryna Point of no return w prawie Unii Europejskiej. Ratione materiae wobec ratione temporis [The Point of no return doctrine. Ratione materiae towards ratione temporis]. Państwo i Prawo [The State and the Law], No. 7, 2017.

6. Grzeszczak M. Skuteczność unijnych procedur ochrony praworządności w stosunku do państw członkowskich [Effectiveness of EU procedures for protecting the rule of law in relation to Member States]. Państwo i Prawo [The State and the Law], No. 6, 2019.

7. Kmieciak Z. Ochrona tymczasowa w sprawie skargi Komisji przeciwko Polsce dotyczącej przepisów ustawy obniżającej wiek przejścia w stan spoczynku sędziów SN. Glosa do postanowienia TSUE z 19.10. 2018 [Interim protection in the case of the Commission's complaint against Poland concerning the provisions of the act lowering the retirement age for the judges of the Supreme Court. Gloss to the CJEU decision of 19 October 2018]. C-619/18 R, Państwo i Prawo [The State and the Law], No. 1, 2019.

8. Kochenov D. Busting the Myths Nuclear: a commentary on Article 7 TEU, EUI Working Paper, Law, No. 10, 2017.

9. Marshall G. The Rule of Law. Its Meaning, Scope and Problems. Cahiers de philosophie politique et juridique No. 24, 1993.

10. Mik C. Komentarz do art. 7 TUE[Commentary on Article 7 TEU]. In: Traktat o Unii Europejskiej. Komentarz [Treaty on European Union. Commentary], Mik C., Czapliński W. (eds.), Warsaw, 2005.

11. Morawska E. Klauzula państwa prawnego w Konstytucji RP na tle orzecznictwa Trybunału Konstytucyjnego [The rule of law clause in the Constitution of the Republic of Poland against the background of the Constitutional Tribunal's jurisprudence]. Torun, 2003.

12. Pech L. The Rule of Law as a Constitutional Principle. Jean Monnet Working Paper Series, No. 4, 2009.

13. Prostak R. Nienaruszalność unijnego systemu wartości jako żywotny interes Unii Europejskiej - krytyczna analiza mechanizmu egzekucji postanowień art. 2 Traktatu o Unii Europejskiej [Inviolability of the EU value system as a vital interest of the European Union a critical analysis of the enforcement mechanism of Article 2 of the Treaty on European Union]. Zaszyty Naukowe Uniwersytetu Ekonomicznego $w$ Krakowie [Cracow Review of Economics and Management], No. 7, 2017.

14. Rulka M. Unijna kontrola praworządności-uwagi de lege ferenda [EU control of the rule of law - de lege ferenda remarks]. Studia Europejskie [Studies in European Affairs], No. 2, 2016. 
15. Safjan M. Rządy prawa a przyszłość Europy [The rule of law and the future and the future of Europe]. Europejski Przeglad Sadowy [European Judiciary Review], No. 8, 2019.

16. Sokolewicz W., Komentarz do art. 7 Konstytucji RP z 2 kwietnia 1997 r. In: Konstytucja Rzeczypospolitej Polskiej. Komentarz, Vol. 5 [Commentary to Article 7 of the Constitution of the Republic of Poland of 2 April 1997]. In: Constitution of the Republic of Poland. Comment]. Garlicki L. (ed.), Warsaw: Wydawnictwo Sejmowe, 2007.

17. Skrzydło W. Konstytucja Rzeczypospolitej Polskiej z dnia 2 kwietnia 1990 r. Komentarz [Constitution of the Republic of Poland of 2 April 1997 Comment]. Kraków, 1998.

18. Taborowski M. Mechanizmy ochrony praworządności państw członkowskich Unii Europejskiej. Studium przebudzenia systemu ponadnarodowego [Mechanisms to protect the rule of law of the European Union Member States. Study of the awakening of the supranational system]. Warsaw: Wolters Kluwer, 2019.

19. Tuleja P. Komentarz do art. 7 Konstytucji RP [Commentary to Article 7 of the Constitution of the Republic of Poland]. In: Konstytucja RP, Komentarz [Constitution of the Republic of Poland. Commentary], Vol. 1, Safjan M., Bosek L. (eds.), Warsaw: CH Beck, 2016.

20. Tuleja P. Zastane pojęcie państwa prawnego [The concept of the rule of law as established]. In: Wronkowska S. (ed.), Zasada demokratycznego państwa prawnego w Konstytucji RP [The principle of a democratic state of law in the Constitution of the Republic of Poland], Warsaw, 2006.

21. Winczorek P. Komentarz do Konstytucji Rzeczypospolitej Polskiej z dnia 2 V 1997 r. [Commentary to Article 7 of the Constitution of the Republic of Poland of 2 April 1997]. Warsaw, 2000.

22. Würtenberger T., Tkaczyński J. W. Nowe ramy Unii Europejskiej na rzecz umocnienia praworządności [a new European Union framework for strengthening the rule of law]. Państwo i Prawo [The State and the Law], No. 9, 2017.

23. Von Bogdandy A. Tyrania wartości? Problemy i drogi europejskiej ochrony praworządności krajowej [Tyranny of values? Issues and methods in the protection of the rule of law in Europe]. Europejski Przegląd Sądowy [European Judiciary Review], No. 4, 2019.

\section{Legislative acts}

1. The Law of 21 November 2018 amending the Law on the Supreme Court (Journal of Laws, item 2507), which entered into force on 01 January 2019.

2. Communication from the Commission to the European Parliament and the Council. a new EU Framework to strengthen the Rule of Law, Strasbourg, 11/03/2014, COM(2014) 158 final.

3. European Council, Conclusions of the Presidency, Copenhagen, 21-22/06/1993, DOC $/ 93 / 3$.

4. Opinion of Advocate General Evgeni Tanchev of 11 April 2019 in case No. C-619/18.

5. Opinion of Advocate General Evgeni Tanchev of 20 June 2019 in case No. C-192/18.

6. Opinion of Advocate General Evgeni Tanchev of 27 June 2019 in joined cases No. C-585/18, C-624/18, C-625/18.

7. White Paper on the reforms of the Polish justice system presented by the Prime Minister of the Republic of Poland Mateusz Morawiecki of 08 March 2018. 


\section{Legal practice}

1. Judgement of the Polish Constitutional Tribunal Ts 216/04 of 9 May 2005, OTK ZU 2006, series B, No. 2, item 87.

2. Judgement of the Polish Constitutional Tribunal K 18/04 of 11 May 2005, OTK-A 2005/5, item 49.

3. Judgement of the CJEU of 11 November 2005, case No. C-144/04, Werner Mangold v. Rüdger Helm.

4. Judgement of the CJEU of 27 February 2018, case No. C-64/16, Associação Sindical dos Juizes Portugueses $v$. Tribunal de Contas.

5. Judgement of the CJEU of 24 June 2019, case No. C 619/18, Commission v. Poland.

\section{Other sources}

1. www.premier.gov.pl

2. www.curia.europa.eu. 